\title{
Education and feminization of the teaching profession
}

\author{
Miriam Stanonik \\ doctoral student of the University of Ljubljana, Slovenia
}

\begin{abstract}
Education or training means a deliberate action of an adult, oriented to another (usually a child, adolescent). Usually the term education is used for the relationship parents towards their children and teachers to pupils. When it comes to education of a child, in particular goes for formatting a child spiritually and characteristically. In a way, it is a tragic truth of childhood that children must fulfill the needs of their parents, which they failed to accomplish in their own childhood. And somehow the children without their knowledge are repairing mistakes that their grandmothers and great-grandmothers had made.

And so mother belongs to a mysterious club of women in which the girl/daughter will enter, when she'll begin to grow up. And mother will teach her with words and even more by example. Therefore she will be the first model of femininity and most scarred model in which the daughter will discover what it means to be a woman. And if the difficult relationship between mother and daughter is not resolved, could be at risk many future relationships in which her (now) adult daughter will be involved or she already is. That is why other educators and teachers are so necessary and irreplaceable. The "outside family" educators assume a key role especially in the period of youth growing up, when children becoming independent and when they distance itself from the primary family.

The famous definition that the school is a substitute for a good home was true once and it is still true today. But we have to contradict the opinion that the teacher can only be a woman, who is neither mother nor wife, and that (starting from the ideology of motherhood) home is the only socially acceptable place for woman. It is a confrontation of a paradoxical role of woman, to whom as bearer of education in the family by inertia allegedly belonged the same role also at school. The nature of the educational activities of teachers has become socially determined
\end{abstract}


role. The beginning offeminization in teaching is definitely occurred in the second half of the 19th century, when the employment opportunities for women in the teaching profession were getting better because of the close integration of raising and teaching of family ideology.

It was considered and thereby agreed by men and women, that this is a profession that is very closely coincides with the image of a diligent mother, exemplary housewife and complete woman.

Keywords: education, educator, teaching profession, feminisation of the teaching profession, women in the teaching profession, woman - mother - teacher

\section{Introduction}

What is education? Why talking about education? Who educates? How to educate? Are the limits needed in education? What are the values? What are the importance of the mother and the importance of the father in the upbringing? Does the school educate? ...

These are just some questions that we ask when thinking about education, about which we do not talk much, and, above all, as a rule, most of us tackles too late.

I embarked answering these questions in a very cliché way, through the Dictionary of Slovenian Literary Language (SSKJ), where we learn that education is „spiritual and character formation, especially in children; systematical development of certain abilities of somebody to perform any work."

Dull! I prefer the thought that I had once traced and says something like that: education is ,just the sort of thing you do rarely, when we want to, and it often happens that we did not want it to happen." All this sounds more like a good aphorism, but in reality, leaves room for philosophical reflection and does not limit us being a definition.

Education begins very early. Even then, when we hold our little „angel”, which we love very much, in our arms, we have a duty to prepare our child for a responsible life. I am convinced that we must begin to talk louder about education. Man is a creature that needs education for existing and for functioning in the community. The human side in a man is the result of education; education at home and in school.

As teachers we are very well aware what the most difficult job in the world is being a parent, as proved by the situation that education is often 
left idling. It is like a boomerang. We get back all the effort we put into education. In a good or bad way... Every parent needs to take responsibility for education in the first place and only then all the other institutions appear, which in this topic can help and advice. Unfortunately, there is no warranty of what is right. And even if we do everything right, in a certain percentage everything can decay.

Education is a complex phenomenon, which integrates several educational fields. A process that integrates every individual. Is the deliberate action of an adult whose target is another person (child, adolescent). Normally we use the concept of education for the relationship of parents to children and teachers to students. Basic elements of the educational process on one hand are the development of an individual's potential and on the other hand the formation of man in accordance to the cultural and civilizational values. Of instilling values if we summarize Šebart (2000), some argue that this is simply the inevitable consequence of the educational process, others point out that this impact may be amended in indoctrination, and the third consider that this fact should be taken into account in the education and exploit the positive sense. Education is about spiritual and character formation of children, youngsters.

Malič and Mužič (the Author, 1988) recognized that the actual process of education is complex and dynamic phenomenon. They define education as a broader process, which covers three specific areas: education in the strict sense (corresponding affective area), education, covering an area of predominantly cognitive and psychomotor skills development. Pediček $(1992,163)$ says that if our education in the broad sense is defined as a social phenomenological category, the education in the strict sense is an activity, which means developing an individual's mental and physical abilities and the creation of his view on the world.

For some authors, education is indoctrination of ideology, for others learning rules of etiquette for third disciplining and adapting to the rules of the school and society. But upbringing can also be something else. As an alternative, education can be the creation of autonomous entities. Yet the ancient philosophers and educators have been emphasizing that education is designed, adapted and dedicated primarily for shaping personality. It is a way of acquiring general culture and civilization. Side by side with education goes gaining of technical or special, expertise knowledge. Both should be conveyed to pupils with the right mix of professional and human authority and integrity by teachers. The authority and integrity are linked to pedagogical eros, which relieves and provides contact of two people (students and teachers) in an open, 
supportive, equal and exciting relationship, based on trust, affection, devotion, patience and reciprocity.

\section{Family education}

The family is the first social system in which the child lives. This relatively closed community with its own characteristics affect the personality of the child at all stages of its development. Parents act on a child in the role of significant others. The child cannot choose significant others, which means that child has to internalize the world that they define for him/her. World of significant others is for children the only objective reality. In the phase of primary socialization child's world is constituted and child accepts the world the way it was determined by significant others. Parents modify child's world three times. First, as parents and as people. The next adjustment is the adjustment to the society, having a child learn all the techniques needed to integrate into society. The third modification is a modification to a family in which a child learns the roles in the family (Čačinovič Vogrinčič 1998, 23).

Father and mother are collective builders of child's personality from birth to adulthood. If the mother is the one who makes the child's experience a relationship of fusion or a strong relationship, the father is the one that helps a child on the way to child's independence. Therefore, the children can develop different characteristics that are presenting a more feminine principle of acts of the man and the other characteristics with male principles.

The symbiosis that has developed between mother and child is essential for healthy child's development. Praper (1992) even claims that symbiosis is one of the most important experiences in life, on which depends the child's future contact with the world and its psychic structure. In this symbiosis it is not merely a "parasitic" attitude, but „a symbiosis between the child and his/her mother, meeting of two entering the relationship with their needs." (ibid, 56) This means that in the relationship both, mother and child are giving. Mother takes care for the child, but also the child fulfills certain mother's tendencies, f. e. child gives her the identity of the mother. Mother is undergoing the experience of motherhood through the child. However, the child gradually has to „step out of his/her subjectivity to the objectivity of the world that is surrounding him/her" and „to give up at least part of their dependence and thus guaranteed security, unconditional acceptance and always accessible consolation" (Žmuc Tomori 1988, 52-53).

Early formation of the child's identity is also linked to the child's identification with the female figure. In order to develop into independent person children 
should gradually begin to liberate from mother's influence and liberate of this love. This means, „the path to manhood (as opposed to femininity) has to make a detour" (Giddens 2000, 120) the father, which is a prerequisite for the independence of dependence on the mother. Mother is often bothered by a strong sense of guilt, because they do not have enough time for the child and they do not have confidence in their educational abilities. What happens is that mother is often excessively lenient to her child, or even bribe the child, which only deepens the symbiotic relationship. Praper (1992) talk about it as a vampire love, when the mother starts to "suck up" the child. Mother becomes jealous of the child, in every child's interest in other people. According to Freud's theory man is the one that transmits moral codes per child and presents outside world to the child. The same think also Lacan (in de Kanter 1987, 22), when he says that the father is the one who introduces and presents the child to the world. The father supports the child's autonomy, because he offers a more instrumental attitude, which is not very emotional.

In the second half of the 20th century the educational style, in which fatherly demand was representing, a decisive role changed to permissive moral educational style, which puts the maternal protection in the foreground. Former values of hard upbringing as punishment and restriction are replaced by values such as emotional acceptance and understanding. Historically, there is an alternation from authoritarian to permissive upbringing. This does not necessarily mean moving from bigger to smaller repressive, but merely a transition from one manner of upbringing to another (Šebart 1990).

Maternity type of education has brought many changes to the education of children and some pathological changes seen in individuals. Female principle is the intuitive part of our personality. This is the deepest and wisest part of us, whether in a man or in a woman. This aspect is receptive and communicates with us through ours intuitions- inner communications, emotions and visions that appear in us. In the female principle, you can feel the love, grace, tenderness, sharing, compassion and kindness. And if we did not pay attention in the waking state, we are trying to achieve it through dreams, emotions, or our physical body. Men principle presents an action - our ability to do things in the physical (real) world, to think, speak, manage our body, or in the worst version as - competition, destructiveness, domination, violence of all kinds and the full supremacy of reason. This male energy is the ability to act whether we are male or female. Woman's aspect accepts creative energy from the universe and man's aspect reflects it through the actions in the external world. But this time we are more interested in the feminine aspect of behavior and education. 
Mother will teach with words and even more as an example. Mother is therefore the first model of femininity and the most labeling model in which the daughter discovers what it means to be a woman. And, if perhaps difficult relationship between mother and daughter is not resolved, other relationships in which adolescent daughter will maintain can be endangered.

Permissive society has also overlooked the true nature of child's developmental needs and psychological rights. Development needs and the resulting rights as analyzed by Pavlović (in Kroflič 2002, 60) are the protection, security and participation. Privacy and security aim to protect the pupil, on the contrary, the participation of the student aim at his personal growth, strengthening responsibility, and finding one's own identity (Pavlović in Kroflič 2002 60). In addition, the third dimension of the child's rights is merely fictitious in permissive upbringing.

Also H. Jeriček (in Kroflič 2007, 57) notes that, by allowing the child too much freedom, we make the child insecure, because he/she cannot decide on matters for which he/she is not competent. Moreover, Jeriček adds, „the child has a right to authority and to limits that are set « (ibid). Therefore Kroflič $(2002,31)$ points out that it is necessary to accept that „the phrase 'child-friendly school / education" is no longer understood in terms of providing 'child's comfortable educational measures', but such measures that are best adapted to the child's development. Therefore unfamiliar teacher is irreplaceable and needed, and takes a key role especially in youthful adolescence, when children are becoming independent and they distance themselves from the primary family.

\section{Education in schools}

Looking at the responsibility to educate, which at least partly assumes the school, we ask ourselves, what are the (real) parents' expectations. Should the school and teachers continue and strengthen what is being undertaken within the family, or rather carry out ungrateful part of education instead of parents?

Research has shown that parents in expectations of the best want their child to be taken care of and educated by the person who will be able to recognize the individual needs of the child and the parents' wishes and expectations. A good teacher will encourage the child to his strengths and she/he will set realistic goals on child's weak areas. Thus the child will gain confidence in his/her own abilities, sense of self-worth and self-esteem. Parents also expect a teacher to be a good therapist and must have a well-developed listening skills, be able to keep confidential things to herself/himself, be able to reconcile with the child, to console child, to sympathize with him and thereby demonstrate that respects the 
child's personality. In that case, the child will gain a sense of security, belonging and connectedness. Child should be raised by a person who is full of optimism, knows how to control his own behavior in various situations, including those that are unpleasant, trusts in herself/himself and be very patient, fair, reliable, resilient, loving, sympathetic, communicative, friendly, vigorous, dynamic and generous. Of all of these, consistency is the most important and the hardest. Through constituency child learns responsibility for his acts. It is required to develop a sense of self-worth in child.

But how? Dr. Reasoner (1992) says he is trying, using his program to develop self-confidence, the ability to problem-solving, leadership, interpersonal relations and perseverance. He is convinced that the majority of students use only about ten per cent of its capacity. "I was interested in knowing what methods could increase creativity in students, their leadership skills, initiative, and capacity for sustained learning. We will have to start to go to school that lasts 50 years. We will have to learn all our lives." Specifically, he formulated five elements that teachers can develop in students:

1. Rouse a sense of security - this is achieved by setting clear boundaries at home and teaching responsible behavior; those who are coming from too strict or non-strict families do not develop a sense of personal responsibility, so they are more susceptible to peer pressure, weight, find it harder to say no to alcohol, drugs, crime, and violence.

2. Develop the sense of identity - everyone should be aware of its own personal value, its merits and drawbacks.

3. Developing the sense of connecting with others - to have the sense for other human beings, understand them and be tolerant.

4. Developing a sense of meaningfulness - Children should be given high goals and ideals and at the same time give them the support to reach them.

5. Developing a sense of ability, competency - they must be trained to solve their own problems.

Nevertheless, how to achieve such a high level of skills? How to become a teacher, who will be able to teach, educate, stimulate? The recipe of Reasoner is not impossible - requires only five basic elements of education. Yet, it is necessary that all these five elements first awaken the teacher itself, who is extremely important as a role model, as an example. The teacher, who has no sense of self-worth, cannot pour forth. The best example is the teacher who follows his life mission. 


\section{Feminization of teaching professions}

The famous definition that the school was a substitute for a good home, applied in the past and still applies today. However, we can definitely not stick to a view that a teacher can only be a woman who is not a mother and a wife (starting from the ideology of motherhood) for whom home is the only socially acceptable place. In this case, we get to cope with a contradictory role of women, who as a carrier of education in the family should have the same role at school.

In the past, the teaching profession was exclusively male profession. The only exception were the nuns, educators/teachers, women monasteries. Men maintained this dominant position until the end of the 19th century, when obligatory education was legislated (Ribarič, 2010).

Having many restrictions made the girls struggle through the system in which they were more or less under authority of men. It was they, who saw in education of women the greatest threat to morality and abandoning those traditional values, which placed women in the narrow family circle. In addition, educated women accounted for „economic” threat, as a competition, which would lead to a reduction in men's earnings. It would reduce the number of marriages, family life would suffer, education would weaken women for their maternity, due to excessive use of the brain, which could „degenerate” their physical fragility. (Milharčič Hladnik 1995, 31-32).

Serše $(1998,49)$ writes: „Women should be at home, to be good housewives and mothers." From these thoughts branches an established belief even at the end of the 19th century. In addition, what is today taken for granted - the right to education for both sexes (from primary education to studying at universities) - was 100 years ago significantly different.

We must not overlook the fact that „schoolchildren's living space consists primarily of parents, teachers and classmates. In this area student sets goals, accepts and carries out the tasks, looks for opportunities and strategies, and tries and motivates himself. The way of experiencing and receiving the concrete circumstances of life are largely dependent on the manner and quality of performance of the tasks, of setting and achieving the goals, recognizing and accepting the values and therefore exercising and „enforcing” himself.

Especially in the school period when children form their cognition, which also affects the social and moral scope, they want to compare to each other and relate their performances, and thus also their 'positioning', and perceptions and self-acceptance is assessed in particular with regard to (non)effectiveness of their classmates. Based on the constancy of comparisons are often on reactions of the adults, children gradually form their self-esteem, which in this case means the 
way or principle conception and acceptance of oneself, which often decisively shapes the child's future" (Gerjolj 2007, 19-20).

The women character of teachers is constantly changing through the development of humankind, while the expectations of the environment remained almost unchanged, that the teacher is committed to doing her job, that it should be a source of high-quality knowledge and a model of conduct and should work always in favor of her client (Toman, 2001). Teacher is a kind of bridge - she is the first to embrace a child outside the family environment, and almost at the same time, her impact on child's development reaches far into his/her future life. Therefore, the person that decides for this profession should be able to bear the responsibility for the safety, education and development of children (Lepičnik Vodopivec, 2007). A good teacher gives the child the support and love, but also sets limits and requirements. Represents the model of identification for the child.

We cannot ignore the link between teaching in the elementary school and ideology about family life. Demonstrating how a woman is, due to her natural role, almost qualified to work in school, the forms that were considered to be in the family were actually brought also to the school field.

Success in school was increasingly associated not with a stiff arm (or teacher's stick), but with "mildness” (women, school moms). “The suitability of the teaching profession for women was not justified only as an excellent preparation for motherhood, but the role of the teacher was defined as a social motherhood. The famous definition that the school was a substitute for a good home is today just as assertive, as it was hundred years ago. It faces us with a paradoxical role of women, to whom as a carrier of education in the family naturally belonged carrying education in school" (Milharčič - Hladnik 1995, 148).

Here we deal with a contradictory role of women, to whom as a carrier of education in the family by inertia belonged the same role at school. The nature of the educational activities of teachers became a socially defined role, which was not just a matter of gendered profession and patriarchal relations, but heritage, which the teaching profession did, and still brings with it. Moreover, of course, is just a continuation of this often enforced view and the idea that the school has to correct or make everything that the family fails to do. Nevertheless, the truth, and the experience is different. Without family, school cannot educate. Without the close cooperation of parents with the school and vice versa, the conditions for a successful and solid education are not met. Therefore, in all the (often fruitless) discussions about school and the family you need to bring a clear dividing line, who's who and what are the competences, what is expected from whom and where their actions exceeds the designated limit. 
This fact is important to consider due to the assumption that this was why the role of mother and teacher is overlapping, and at teaching their own children comes to unforeseen problems/shortcomings. Children want a teacher at school and mother at home, but they mix both images. Children need a mention from their mother and encouragement from their teachers; they seek for recognition from a teacher, but they must overhear the praise because otherwise classmates exclude them because a teacher has more affection for them than for the others. When their mother examines them, the mother/teacher requires more knowledge from their own children than from the others out of fear that she would be impartial.

The survey results show that there are more women working within school and teaching who duplicate their motherly role. They do not feel it as particularly burdensome and damaging for their relations with children. They feel that they can set the limits and separate the school from the family. Their justice and impartiality at checking skills were evaluated as good and they stressed that they were always trying to achieve that, without exposing their children positively or negatively. As mothers/teachers, it was easier for them to monitor their child's development, provide further explanation, follow the child's progress, and they were able to combine the natural and social vocation in its fullness. Initially no one remembers great surprises.

Later, this one surprise was the most exposed, when a daughter, who is at home explaining to her father about what was discussed and worked at school by "her teacher" (a mother who was listening). All these children recognize that the duplication of their parents' teaching/parental role was a difficult experience for them and no one even today, after so many years, does not remain untouched. Many are not able to process these injuries in relationships. What hurts them the most is, that parents did not stand for them, that they were strictly evaluated, they had to know more, they were not allowed to afford child's misbehavior, that they should always be exemplary „behaved”, that they were often teased and even excluded by classmates, if they were successful. They felt limited in the classroom, the schoolyard and partly at home. At home they missed a mother, who did not have to know everything they did at school, and in school they missed the teacher who would loudly give them a recognition in front of other classmates and maybe give them back a lost a place in the classroom.

\section{References}

Dangl, Oskar. 1988. O pojmih vzgoje in izobraževanja. Sodobna pedagogika, 9-10 (440-442). Bahovec, Eva D. 1992. Vzgoja med gospodstvom in analizo. Krt, Ljubljana. 
Čačinovič Vogrinčič, Gabi. 1998. Psihologija družine. Ljubljana: Znanstveno in publicistično središče.

Gerjolj, Stanko. 2007. Psihologija vzgoje in izobraževanja. Ljubljana, Maribor: Teološka fakulteta.

Kanter, R. De. 1987. A Father is a Bag Full of Money: The Person, the Position and the Symbol of the Father. In: Knijn, T., Mulder. A.C. (eds.). Unravelling Fatherhood. Dordrecht - Holland/ Providence, USA, Floris Publications, 6-27.

Kroflič, Robi. 2002. Izbrani pedagoški spisi: Vstop v kurikularne teorije. Ljubljana: Zavod Republike Slovenije za šolstvo.

Kroflič, Robi. 2007. Vzgoja za odgovornost onkraj razsvetljenske paradigme (Od razvoja odgovora-zmožnosti k spoštljivemu odnosu in razvoju etične zavesti). In: Sodobna pedagogika, let. 58 (124), posebna izdaja, 56-71.

Lepičnik Vodopivec, Jurka. 2007. Razlogi za izbiro poklica vzgojitelja predšolskih otrok. Pedagoška obzorja, 22 (3-4), 114-125.

Marentič Požarnik, Barica. 2000. Psihologija pouka in učenja. Ljubljana: DZS .

Milharčič-Hladnik, Mirjam. 1995. Šolstvo in učiteljice na Slovenskem. Ljubljana: Znanstveno in publicistično središče.

Millot, Catherine. 1983. Anti-pedagog Freud. In: Gospodstvo, vzgoja, analiza. Zbornik. DDU Univerzum, Ljubljana, 184-217.

Pediček, Franc. 1992/1. »Pedagogika danes«. Maribor: Obzorja Maribor.

Praper, Peter. 1992. Tako majhen, pa že nervozen!? Predsodki in resnice o nevrozi pri otroku. Nova Gorica: Educa.

Ribarič, Mateja. 2010. Izobraževanje žensk in vloga žensk v šolstvu v preteklosti. In: Pungerčar Majda, Furlan Iris (eds.). Vloga žensk v preteklosti. Ljubljana: Zveza prijateljev mladine Slovenije, Komisija za delo zgodovinskih krožkov, 35-46.

Reasoner, Robert W. 1992. Building Self-Esteem in the Elementary Schools. Consulting Psychologists Pr.

Salecl, Renata. 1988. Vzgoja kot »bistveno drugotno stanje«. In: Problemi - šolsko polje. Ljubljana, nr. 11, 119-125.

Serše, Aleksandra. 1998. Ženske naj bodo doma, naj bodo dobre gospodinje in matere. In: Mrgole Jukič Tjaša (ed.). Izobraževanje in zaposlovanje žensk nekoč in danes I. Ptuj: Zgodovinski arhiv, 49 - 71.

Slovar slovenskega knjižnega jezika. 2004. Izdala Slovenska akademija znanosti in umetnosti in Znanstvenoraziskovalni center Slovenske akademije znanosti in umetnosti, Inštitut za slovenski jezik Frana Ramovša. Ljubljana: Cankarjeva založba.

Šebart K., Mojca. 1990. O namenih in stilih vzgajanja nekoliko drugače. In: Iskanja, nr. 9, 48-96. Šebart K., Mojca. 2000. Šola, vzgoja in vrednote. Sodobna pedagogika, 51(1), 64-80.

Toman, Uršula. 2001. Poklic vzgojiteljica, vzgojitelj. Vzgojiteljica, 3(3), 23-25.

Žmuc Tomori, Martina. 1988. Klic po očetu. Ljubljana: Cankarjeva založba. 